\title{
Histopathological and Immunohistochemical Study of the Prognostic Significance of Cox2 and CDX2 Expression in the Available Cases of Colorectal Carcinoma
}

\author{
HEND A. EL-REFAEY, M.Sc.; ASMAA E. BEDEER, M.D.; HASSAN T. SHOEIR, M.D. and \\ HUSSEIN M. GHORABA, M.D. \\ The Department of Pathology, Faculty of Medicine, Tanta University
}

\begin{abstract}
Background: Colorectal cancer is the third most common cancer worldwide. In Egypt, the relative frequency of colorectal cancer is about $9-12 \%$ with high male predominance $3: 1$. Several proteins are associated with the development and progression of colorectal cancer including Cox 2 and CDX2 proteins. However, it is still controversial whether Cox 2 and CDX2 expression can be regarded as prognostic factors for colorectal cancer patients.
\end{abstract}

Aim of Study: The purpose of this study is to detect the immunohistochemical expression of Cox 2 and CDX2 in colorectal carcinoma and correlate their expression with the available clinicopathological parameters to illustrate their prognostic role.

Material and Methods: Fifty cases of colorectal carcinoma in colectomy specimens were collected retrospectively. They were stained by $\mathrm{H} \& \mathrm{E}, \mathrm{Cox} 2$ and $\mathrm{CDX} 2$ for immunohistochemical study. The relations between their expression and the available clinicopathological parameters were evaluated.

Results: Cox 2 expression in colorectal carcinoma showed statistically significant relation with depth of tumor invasion, lymph node status, distant metastasis and tumor stage. CDX2 expression showed statistically significant inverse relation with histopathological grade, depth of tumor invasion, lymph node status, distant metastasis, tumor stage and vascular invasion. There was statistically significant relation between the immunohistochemical expression of Cox 2 and CDX2 in colorectal carcinoma.

Conclusions: Expression of Cox 2 and loss of CDX2 are usually related to poor outcome and metastasis in colorectal cancer.

Key Words: Cox $2-C D X 2-$ Colorectal carcinoma - Immunohistochemistry-Prognosis.

Correspondence to: Dr. Hend A. El-Refaey, The Department of Pathology, Faculty of Medicine, Tanta University

\section{Introduction}

COLORECTAL cancer is the third most common cancer worldwide [1] . It is a very common malignant tumor of the digestive tract, with about 1.2 million new cases and 600,000 deaths worldwide each year [2] . Colorectal cancer is the third most commonly diagnosed malignancy in males, after lung cancer and prostatic cancer and the second in females, after breast carcinoma [3]. It is the second most frequent cause of death by cancer [4]

Colorectal cancer is the $7^{\text {th }}$ most common cancer in Egypt, representing 3.47\% of male cancers and $3 \%$ of female cancers $[\mathbf{5 , 6}]$. In Egypt, the relative frequency of CRC is about $9-12 \%$ with high male predominance [7]. It is the third most common tumor in males after urinary bladder and lymphohemopoietic malignancies, and in females it ranks fifth after breast, lymphohemopoietic, cervical, and urinary bladder cancers. Recently, interest in Egyptian colorectal cancer has been raised when clinical studies revealed a high incidence of the disease among the young Egyptian population [8] In Egypt, colon cancer was commonly diagnosed in elder people with a mean age about 53 year-old, which is still more than a decade younger than the corresponding age in the USA (69 in men and 73 in women) $[6,9]$. Alterations and changes in the traditional Egyptian diet, introduction of new types of foods and eating habits such as consumption of processed or semi-processed, tinned or cooked meats, fried potatoes, hamburger, and pizza are taking place. Fast foods became popular as well as physical inactivity and smoking which might lead to increasing CRC among Egyptian population [7]. 
Certain molecular markers involved in CRC tumorigenesis have verified prognostic and predictive impact in addition to conventional TNM staging classification which is considered the major prognostic indicator [10].

Several epidemiological researches reported a $40-50 \%$ decrease in the relative risk of colorectal cancer in persons chronically using Non-Steroidal Anti-Inflammatory Drugs (NSAIDs) indicating that these drugs might have a chemoprotective and possibly chemotherapeutic effect [11,12]. The best known targets of NSAIDs are cyclooxygenase (Cox) enzymes [13]. Many studies have focused on the role of Cyclooxygenase 2 (Cox2) in tumor development and progression [14]. It is a ratelimiting synthase which catalyzes the metabolism of Arachidonic Acid (AA) to PGs. Cox2 is an inducible enzyme and is associated with inflammatory diseases and carcinogenesis [15]. It is encoded by the gene located on chromosome 1 at q31.1 [16] . Overexpression of Cox 2 plays a central role in intestinal tumorigenesis. In fact, elevated levels of Cox2-derived PGE2 are associated with resistance to apoptosis [17]; stimulation of cell proliferation; simulation of cell migration and angiogenesis [18].

Caudal-related homeobox transcription factor 2 (CDX2) is an intestine-specific transcription factor essential for intestinal development and differentiation $[\mathbf{1 9 , 2 0 ]}$. It is encoded by CDX2 gene which is a member of the caudal-related homeobox gene family [21] that maps to the ParaHox gene cluster [22] in chromosome 13q12 [23]. The expression of CDX2 in adults is restricted to the intestine, from the duodenum to the rectum. CDX2 is regarded as a specific marker of the intestinal epithelial cells that can be utilized for identifying the colorectal origin of metastatic adenocarcinomas [24] The role of CDX2 protein during CRC development remains controversial, as different studies suggest both negative and positive modulation of tumourigenesis [23] . CDX2 has been proposed as a tumor suppressor in colon cancer [24,25], but CDX2 expression is seldom lost in colon cancer tissue, and the gene is rarely mutated [26,27]. Furthermore, several studies have found that CDX2 gene is often amplified in colon cancer, suggesting a lineage survival oncogene function in some tumors [28,29]

\section{Material and Methods}

This study was carried out on 50 cases of colorectal carcinoma in the form of colectomy specimen. These cases were collected retrospectively from the archives of Pathology Department, Faculty of Medicine, Tanta University and from some private laboratories during the period of the research from February 2016 to December 2017 and patients' data were obtained from files of surgery and oncology reports. Approval from Research Ethics Committee (REC), Faculty of Medicine, Tanta University was taken antecedent to conducting study.

Cases were classified microscopically according to the $4^{\text {th }}$ edition of the World Health Organization (WHO) classification system, 2010 [30,31] . Cases were graded traditionally using the three-tiered system into well differentiated (Grade 1), moderately differentiated (Grade 2 ) and poorly differentiated (Grade 3 ) carcinomas according to the WHO criteria which was based on the extent of glandular differentiation as the following [32]

Grade 1: Showing more than $95 \%$ of gland formation.

\section{Grade 2: Gland formation ranged between $50 \%$} and $95 \%$.

Grade 3: Gland formation was lower than $50 \%$.

Pathological staging of the studied colorectal carcinomas was determined according to the recommendations of the 8 th edition of AJCC, Cancer Staging Manual, 2017 by using the TNM staging system [33]

Immunohistochemical staining was performed on $10 \%$ formalin fixed, paraffin embedded tissue blocks for evaluation of Cox 2 and CDX2 expression. Sections were immunohistochemically labeled, using primary antibodies to Cox 2 (Ready to use Rabbit monoclonal antibody, Thermo Fisher Scientific, USA) and CDX2 (DAK-CDX2 clone, ready to use mouse monoclonal antibody, DAKO, Egypt). Cox 2 expression was mainly cytoplasmic in the tumor cells [34]. Immunostaining evaluation was performed using a semi-quantitative scoring system by estimating the percentage of the tumor cells stained and staining intensity [35]. The extent of staining was graded as follows: 0 -staining in less than $1 \%$ of tumor cells; 1 -staining in 1-20\%; 2 - staining in 20-50\%; and 3-staining in more than $50 \%$. Overall intensity of staining was also assessed as follows: 0 no staining; 1 weak staining; 2 moderate staining; and 3 strong staining. Final scores (range from 0 to 9) were obtained by multiplying staining extents and intensities. Final scores were described as follows: 0 , no expression; 1 to 3 , weak expression; 4-6, moderate expression; and 7-9, strong expression. For statistical analysis, no expression and weak expression were combined and 
described as negative for expression, and moderate and strong expression were combined and described as positive for expression [14]. Nuclear CDX2 were scored as the percentage of positive tumor cells [24]. The tumor was considered to be positive for CDX2 when it showed at least $20 \%$ of positive cells $[\mathbf{2 4 , 3 6}]$

Chi-square test was used as a test of significance to evaluate the association between categorized variables and $p$-value $<0.05$ was considered statistically significant. Statistical analyses were performed using SPSS software, Version 12.0.

\section{Results}

The clinicopathological characteristics of the studied cases were summarized in (Table 1). We immunohistochemically evaluated 50 cases of colorectal carcinoma specimens for Cox 2 and CDX2 expression and correlated with different clinicopathological characteristics (Tables 2,3).

Out of 50 studied colorectal carcinoma cases, 38 cases $(76 \%)$ were Cox 2 positive including 23 cases $(46 \%)$ of moderate expression and 15 cases (30\%) of strong expression, while 12 cases $(24 \%)$ were Cox 2 negative including 11 cases $(22 \%)$ of weak expression and one case (2\%) of no expression. There was a statistically significant correlation between Cox 2 expression and the depth of tumor invasion $(p$-value $=0.024)$, lymph node status $(p$ value $=0.009)$, distant metastasis $(p$-value $=0.035)$ and TNM stage ( $p$-value $=0.001)$. Cox 2 expression was not significantly correlated with histopathological type, histopathological grade, vascular invasion and perineural invasion ( $p$-value $=0.091$, $0.405,0.385$ and 0.329 respectively).

Out of 50 studied colorectal carcinoma cases, 39 cases $(78 \%)$ were $\mathrm{CDX} 2$ positive, while 11 cases $(22 \%)$ were CDX2 negative. There was a statistically significant inverse correlation between CDX2 expression and histopathological grade ( $p$ value $=0.005)$, depth of tumor invasion $(p$-value $=$ $0.001)$, lymph node status ( $p$-value $=0.001)$, distant metastasis $(p$-value $=0.001)$, TNM stage $(p$-value $=$ $0.002)$ and vascular invasion ( $p$-value $=0.001)$. CDX2 expression was not significantly correlated with histopathological type and perineural invasion ( $p$-value $=0.097$ and 0.248 respectively). The relation between Cox 2 immunohistochemical score and CDX2 immunohistochemical staining in the studied cases was statistically significant $(p$-value $=$ $0.035)$.
Table (1): Clinicopathological characteristics of the studied cases.

\begin{tabular}{|c|c|c|}
\hline Clinicopathological characteristics & No. & $\%$ \\
\hline \multicolumn{3}{|l|}{ Age: } \\
\hline$\bullet<40$ & 14 & 28.0 \\
\hline -40-60 & 18 & 36.0 \\
\hline$\bullet>60$ & 18 & 36.0 \\
\hline \multicolumn{3}{|l|}{ Sex: } \\
\hline - Male & 26 & 52.0 \\
\hline - Female & 24 & 48.0 \\
\hline \multicolumn{3}{|l|}{ Tumor location: } \\
\hline - Right colon & 17 & 34.0 \\
\hline - Left colon & 20 & 40.0 \\
\hline • Rectum & 13 & 26.0 \\
\hline \multicolumn{3}{|l|}{ Tumor size: } \\
\hline$\cdot<5 \mathrm{~cm}$ & 23 & 46.0 \\
\hline$\bullet>5 \mathrm{~cm}$ & 27 & 54.0 \\
\hline \multicolumn{3}{|l|}{ Gross appearance: } \\
\hline • Fungating & 17 & 34.0 \\
\hline - Ulcerating & 17 & 34.0 \\
\hline - Infiltrating & 16 & 32.0 \\
\hline \multicolumn{3}{|l|}{ Histopathological types: } \\
\hline - Conventional adenocarcinoma & 30 & 60.0 \\
\hline • Mucinous carcinoma & 10 & 20.0 \\
\hline - Signet ring carcinoma & 3 & 6.0 \\
\hline $\begin{array}{l}\text { - Adenocarcinoma with } \\
\text { neuroendocrine differentiation }\end{array}$ & 2 & 4.0 \\
\hline • Medullary carcinoma & 1 & 2.0 \\
\hline - Adenosquamous carcinoma & 1 & 2.0 \\
\hline - Small cell carcinoma & 1 & 2.0 \\
\hline - Large cell carcinoma & 1 & 2.0 \\
\hline - Papillary adenocarcinoma & 1 & 2.0 \\
\hline \multicolumn{3}{|l|}{ Histopathological grade: } \\
\hline - Grade I & 5 & 10.0 \\
\hline - Grade II & 25 & 50.0 \\
\hline - Grade III & 20 & 40.0 \\
\hline \multicolumn{3}{|l|}{ Vascular invasion: } \\
\hline - Present & 12 & 24.0 \\
\hline - Absent & 38 & 76.0 \\
\hline \multicolumn{3}{|l|}{ Perineural invasion: } \\
\hline - Present & 8 & 16.0 \\
\hline - Absent & 42 & 84.0 \\
\hline \multicolumn{3}{|l|}{ Depth of invasion: } \\
\hline • T1 & 2 & 4.0 \\
\hline - $\mathrm{T} 2$ & 4 & 8.0 \\
\hline - T3 & 26 & 52.0 \\
\hline • $\mathrm{T} 4$ & 18 & 36.0 \\
\hline \multicolumn{3}{|l|}{ Lymph node status: } \\
\hline$\bullet$ NO & 20 & 40.0 \\
\hline$\bullet \mathrm{N} 1$ & 16 & 32.0 \\
\hline$\cdot \mathrm{N} 2$ & 14 & 28.0 \\
\hline \multicolumn{3}{|l|}{ Distant metastasis: } \\
\hline$\bullet$ M1 & 11 & 22.0 \\
\hline • M0 & 39 & 78.0 \\
\hline \multicolumn{3}{|l|}{ TNM staging: } \\
\hline - Stage I & 6 & 12.0 \\
\hline - Stage II & 14 & 28.0 \\
\hline - Stage III & 19 & 38.0 \\
\hline - Stage IV & 11 & 22.0 \\
\hline
\end{tabular}


Table (2): Correlation between Cox2 immunohistochemical score and different clinicopathological parameters.

\begin{tabular}{|c|c|c|c|c|c|c|c|}
\hline \multirow{3}{*}{ Variables } & \multirow{3}{*}{ n. } & \multicolumn{4}{|c|}{ COX2 immunohistochemical score } & \multirow{3}{*}{$x^{2}$} & \multirow{3}{*}{$\mathrm{MC}_{p}$} \\
\hline & & \multicolumn{2}{|c|}{ Positive } & \multicolumn{2}{|c|}{ Negative } & & \\
\hline & & n. & $\%$ & n. & $\%$ & & \\
\hline \multicolumn{8}{|l|}{ Type: } \\
\hline - Conventional adenocarcinoma & 30 & 20 & 66.7 & 10 & 33.3 & 13.675 & 0.091 \\
\hline - Mucinous carcinoma & 10 & 10 & 100.0 & 0 & 0.0 & & \\
\hline - Signet ring carcinoma & 3 & 3 & 100.0 & 0 & 0.0 & & \\
\hline - Conventional with neuroendocrine differentiation & 2 & 2 & 100.0 & 0 & 0.0 & & \\
\hline - Medullary carcinoma & 1 & 0 & 0.0 & 1 & 100.0 & & \\
\hline - Adenosquamous carcinoma & 1 & 1 & 100.0 & 0 & 0.0 & & \\
\hline - Small cell carcinoma & 1 & 0 & 0.0 & 1 & 100.0 & & \\
\hline - Large cell carcinoma & 1 & 1 & 100.0 & 0 & 0.0 & & \\
\hline - Papillary carcinoma & 1 & 1 & 100.0 & 0 & 0.0 & & \\
\hline \multicolumn{8}{|l|}{ Grade: } \\
\hline - Grade I & 5 & 3 & 60.0 & 2 & 40.0 & 1.809 & 0.405 \\
\hline - Grade II & 25 & 18 & 72.0 & 7 & 28.0 & & \\
\hline - Grade III & 20 & 17 & 85.0 & 3 & 15.0 & & \\
\hline \multicolumn{8}{|l|}{ The depth of the invasion: } \\
\hline$\bullet \mathrm{T} 1$ & 2 & 0 & 0.0 & 2 & 100.0 & 9.467 & $0.024 *$ \\
\hline$\bullet \mathrm{T} 2$ & 4 & 2 & 50.0 & 2 & 50.0 & & \\
\hline$\bullet \mathrm{T} 3$ & 26 & 20 & 76.9 & 6 & 23.1 & & \\
\hline$\cdot \mathrm{T} 4$ & 18 & 16 & 88.9 & 2 & 11.1 & & \\
\hline \multicolumn{8}{|l|}{ The lymph node status: } \\
\hline$\cdot$ NO & 20 & 11 & 55.0 & 9 & 45.0 & 9.498 & $0.009 *$ \\
\hline$\bullet \mathrm{N} 1$ & 16 & 13 & 81.2 & 3 & 18.8 & & \\
\hline$\cdot \mathrm{N} 2$ & 14 & 14 & 100.0 & 0 & 0.0 & & \\
\hline \multicolumn{8}{|l|}{ Distant metastasis: } \\
\hline$\bullet \mathrm{M} 0$ & 39 & 27 & 69.2 & 12 & 30.8 & 4.453 & $0.035^{*}$ \\
\hline$\bullet$ M1 & 11 & 11 & 100.0 & 0 & 0.0 & & \\
\hline \multicolumn{8}{|l|}{ Tumor stage: } \\
\hline - Stage I & 6 & 2 & 33.3 & 4 & 66.7 & 11.217 & $0.001 *$ \\
\hline - Stage II & 14 & 9 & 64.3 & 5 & 35.7 & & \\
\hline - Stage III & 19 & 16 & 84.2 & 3 & 15.8 & & \\
\hline - Stage IV & 11 & 11 & 100.0 & 0 & 0.0 & & \\
\hline \multicolumn{8}{|l|}{ The vascular invasion: } \\
\hline - Present & 12 & 8 & 66.7 & 4 & 33.3 & 0.754 & 0.385 \\
\hline - Abscent & 38 & 30 & 78.9 & 8 & 21.1 & & \\
\hline \multicolumn{8}{|l|}{ The perineural invasion: } \\
\hline - Present & 8 & 5 & 62.5 & 3 & 37.5 & 0.952 & 0.329 \\
\hline - Absent & 42 & 33 & 78.6 & 9 & 21.4 & & \\
\hline
\end{tabular}


Table (3): Correlation between CDX2 immunohistochemical staining and different clinicopathological parameters.

\begin{tabular}{|c|c|c|c|c|c|c|c|}
\hline \multirow{3}{*}{ Variables } & \multirow{3}{*}{ n. } & \multicolumn{4}{|c|}{ CDX2 immunohistochemical staining } & \multirow{3}{*}{$x^{2}$} & \multirow{3}{*}{$\mathrm{MC}_{p}$} \\
\hline & & \multicolumn{2}{|c|}{ Positive } & \multicolumn{2}{|c|}{ Negative } & & \\
\hline & & $\mathrm{n}$. & $\%$ & n. & $\%$ & & \\
\hline \multicolumn{8}{|l|}{ Type: } \\
\hline - Conventional adenocarcinoma & 30 & 26 & 86.7 & 4 & 13.3 & 13.450 & 0.097 \\
\hline - Mucinous carcinoma & 10 & 7 & 70.0 & 3 & 30.0 & & \\
\hline - Signet ring carcinoma & 3 & 2 & 66.7 & 1 & 33.3 & & \\
\hline - Conventional with neuroendocrine differentiation & 2 & 2 & 100.0 & 0 & 00.0 & & \\
\hline - Medullary carcinoma & 1 & 0 & 00.0 & 1 & 100.0 & & \\
\hline - Adenosquamous carcinoma & 1 & 0 & 00.0 & 1 & 100.0 & & \\
\hline - Small cell carcinoma & 1 & 1 & 100.0 & 0 & 00.0 & & \\
\hline - Large cell carcinoma & 1 & 1 & 100.0 & 0 & 00.0 & & \\
\hline - Papillary carcinoma & 1 & 0 & 00.0 & 1 & 100.0 & & \\
\hline \multicolumn{8}{|l|}{ Grade: } \\
\hline - Grade I & 5 & 5 & 100.0 & 0 & 0.0 & 10.431 & $0.005^{*}$ \\
\hline - Grade II & 25 & 23 & 92.0 & 2 & 8.0 & & \\
\hline - Grade III & 20 & 11 & 55.0 & 9 & 45.0 & & \\
\hline \multicolumn{8}{|l|}{ The depth of the invasion: } \\
\hline$\bullet \mathrm{T} 1$ & 2 & 2 & 100.0 & 0 & 0.0 & 13.018 & $0.001 *$ \\
\hline$\bullet \mathrm{T} 2$ & 4 & 4 & 100.0 & 0 & 0.0 & & \\
\hline$\bullet \mathrm{T} 3$ & 26 & 24 & 92.3 & 2 & 7.7 & & \\
\hline$\cdot \mathrm{T} 4$ & 18 & 9 & 50.0 & 9 & 50.0 & & \\
\hline \multicolumn{8}{|l|}{ The lymph node status: } \\
\hline$\cdot$ NO & 20 & 19 & 95.0 & 1 & 5.0 & 14.286 & $0.001 *$ \\
\hline$\cdot \mathrm{N} 1$ & 16 & 14 & 87.5 & 2 & 12.5 & & \\
\hline$\cdot \mathrm{N} 2$ & 14 & 6 & 42.9 & 8 & 57.1 & & \\
\hline \multicolumn{8}{|l|}{ Distant metastasis: } \\
\hline - M0 & 39 & 35 & 89.7 & 4 & 10.3 & 14.247 & $0.001 *$ \\
\hline$\cdot \mathrm{M} 1$ & 11 & 4 & 36.4 & 7 & 63.6 & & \\
\hline \multicolumn{8}{|l|}{ Tumor stage: } \\
\hline - Stage I & 6 & 6 & 100.0 & 0 & 0.0 & 15.033 & $0.002 *$ \\
\hline - Stage II & 14 & 13 & 92.9 & 1 & 7.1 & & \\
\hline - Stage III & 19 & 16 & 84.2 & 3 & 15.8 & & \\
\hline - Stage IV & 11 & 4 & 36.4 & 7 & 63.6 & & \\
\hline \multicolumn{8}{|l|}{ The vascular invasion: } \\
\hline - Present & 12 & 4 & 33.3 & 8 & 66.7 & 18.358 & $0.001 *$ \\
\hline - Abscent & 38 & 35 & 92.1 & 3 & 7.9 & & \\
\hline \multicolumn{8}{|l|}{ The perineural invasion: } \\
\hline - Present & 8 & 5 & 62.5 & 3 & 37.5 & 1.333 & 0.248 \\
\hline - Absent & 42 & 34 & 81.0 & 8 & 19.0 & & \\
\hline
\end{tabular}




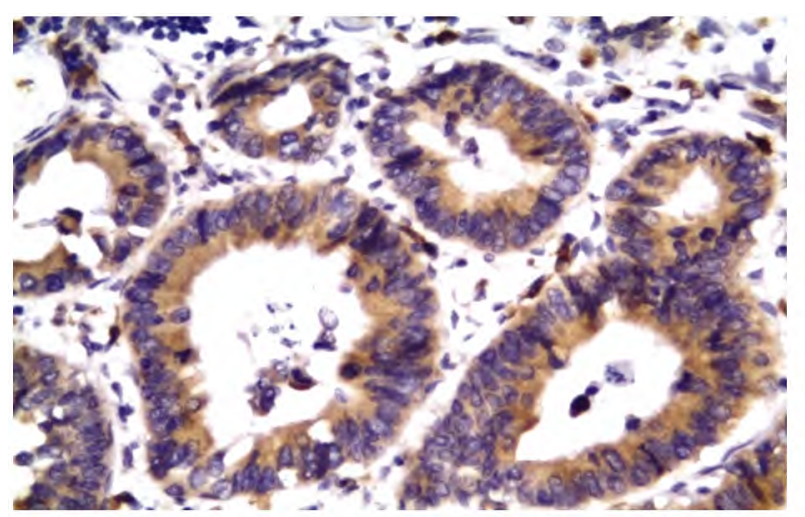

(A)

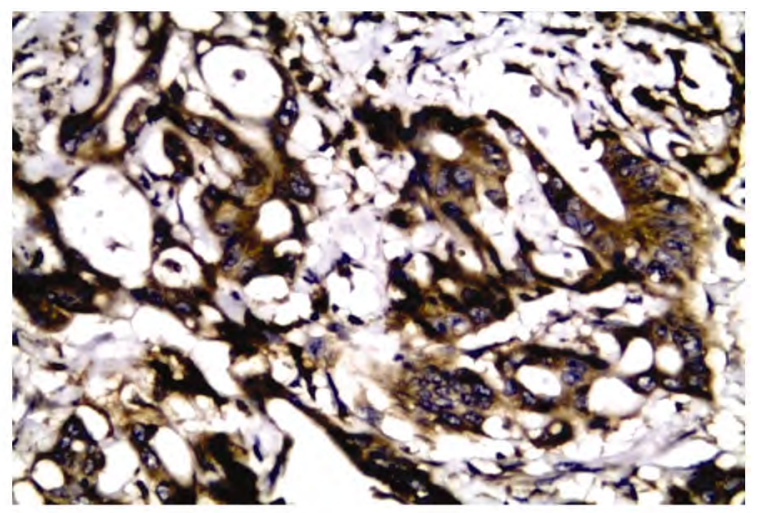

(B)

Fig. (1): (1A) Conventional adenocarcinoma (grade I) showing weak cytoplasmic Cox2 expression, negative score (3) (X400). (1B) Conventional adenocarcinoma (grade III) showing strong cytoplasmic Cox2 expression, positive score (9) (X400).

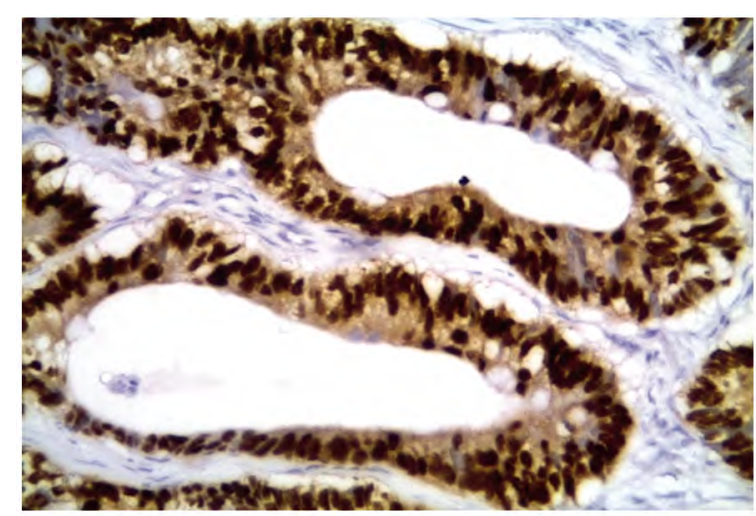

(A)

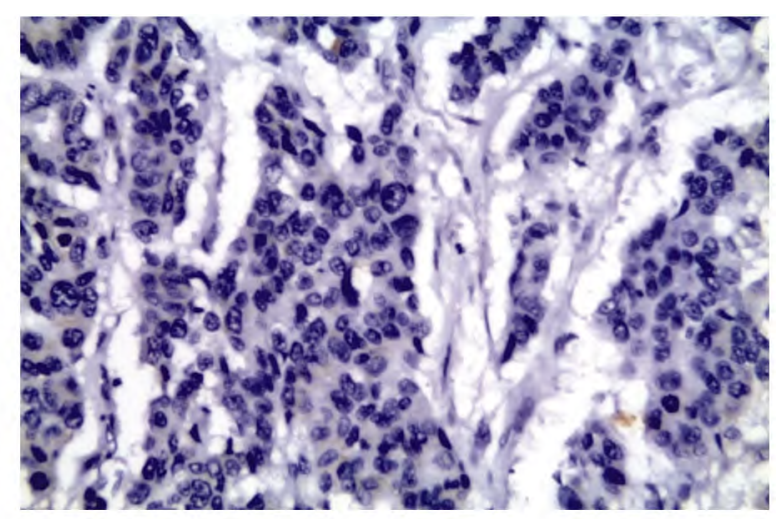

(B)

Fig. (2): (2A) Conventional adenocarcinoma (grade I) showing positive nuclear CDX2 staining (X400). (2B) Conventional adenocarcinoma (grade III) showing negative nuclear CDX2 staining (X400).

\section{Discussion}

Cox 2 is a rate-limiting synthase which catalyzes the metabolism of Arachidonic Acid (AA) to PGs. Cox2 is an inducible enzyme and is associated with inflammatory diseases and carcinogenesis [15] . It is encoded by the gene located on chromosome 1 at q31.1 [16]. Overexpression of Cox2 plays a central role in intestinal tumorigenesis. In fact, the elevated level of Cox2-derived PGE2 is associated with resistance to apoptosis [17]; stimulation of cell proliferation; simulation of cell migration and angiogenesis [18].

Cox 2 expression was associated with increased depth of tumor invasion, increased lymph node metastasis, distant metastasis and increased tumor stage. From that, Cox 2 expression was associated with poor prognosis of colorectal carcinoma which was in agreement with other studies who reported that Cox 2 expression is a useful poor prognostic marker in CRC $[34,35,37-40]$. In contrast, Fux et al., [41] and Lim et al., [42] demonstrated that Cox2 overexpression has little prognostic impact in CRC.
Besides, Wu et al., [43] and Yamac et al., [44] failed to prove a prognostic relevance of Cox 2 expression in CRC.

Cox2 expression was observed to increase with increased depth of the tumor invasion and the relation between Cox 2 score and depth of invasion (T) was statistically significant. Similarly, Lim et al., [14] reported that Cox 2 expression was significantly associated with infiltration depth. In contrast, Lim et al., [42] and Shin et al., [46] found no significant correlation between Cox 2 expression and depth of invasion. Cox 2 expression was observed to increase with increased lymph node metastasis and the relation between Cox 2 score and lymph node status $(\mathrm{N})$ was statistically significant. Similarly, Xiong et al., [45] and Shin et al., [46] reported that Cox2 expression was significantly associated with lymph node metastasis. In contrast, Elzagheid et al., [34] and Mahmoud et al., [47] detected no association between Cox 2 expression and lymph node metastasis. Cox 2 expression was observed to increase in cases with distant metastasis than those with no documented distant metastasis 
and the relation between Cox 2 score and distant metastasis (M) was statistically significant. Similarly, Wan et al., [48] and Al-Maghrabi et al., [40] detected significant correlation between Cox2 expression and distant metastasis. In contrast, Okudur et al., [39] failed to demonstrate a statistically significant correlation between Cox 2 and the presence of metastases. Yamauchi et al., [37] and Xiong et al., [45] reported that Cox 2 expression was correlated with hepatic metastasis in contrast with Shin et al., [46] who found no relation between Cox 2 expression and hepatic metastasis. Cox 2 immunohistochemical score was observed to increase with increased stage of the tumor and the relation between Cox 2 score and tumor stage in the studied colorectal carcinoma cases was statistically significant. Similarly, Al-Maghrabi et al., [40] and Elzagheid et al., [34] reported statistically significant correlation between Cox 2 expression and tumor stage. In contrast, Lim et al., [42] and Mahmoud et al., [47] detected no significant association between Cox 2 expression and tumor stage.

Caudal-related homeobox transcription factor 2 (CDX2) is an intestine-specific transcription factor essential for intestinal development and differentiation $[19,20]$. It is encoded by CDX2 gene which is a member of the caudal-related homeobox gene family [21] that maps to the ParaHox gene cluster [22] in chromosome 13q12 [23].

The role of CDX2 protein during CRC development remains controversial, as different studies suggest both negative and positive modulation of tumourigenesis [23].

CDX2 expression in the current study showed statistically significant inverse correlation with histopathological grade, depth of tumor invasion, lymph node status, distant metastasis, TNM stage and vascular invasion. From that, loss of CDX2 expression was associated with poor prognosis of colorectal carcinoma which was in agreement with other studies as Dalerba et al., [49] and Bonetti et al., [36] who suggested that loss of CDX2 expression may be useful as a prognostic marker for advanced CRCs. Besides, Kim et al., [50] demonstrated that the CDX2 negative phenotype was an independent adverse prognostic factor for MSI-H CRC. There was statistically significant inverse relation between CDX2 immunohistochemical staining and the histopathological grade. Loss of CDX2 immunohistochemical staining increased with increased tumor histopathological grade. Similarly, Oslen et al., [53] and Bonetti et al., [36] reported significant correlation between CDX2 loss and poor differentiation grade. Besides, Kim et al., [50] found that CDX2 loss was significantly associated with poor differentiation in MSI-H CRC tissues and Lugli et al., [54] found that the loss of CDX2 expression is associated with a higher tumor grade in mismatch repair-proficient (MSS or MSI-low) CRCs. There was statistically significant inverse relation between CDX2 immunohistochemical staining and the depth of tumor invasion (T). Loss of CDX2 immunohistochemical staining increased with increased depth of tumor invasion (T). Similarly, Bae et al., [24] reported that loss of CDX2 expression was significantly associated with depth of tumor invasion (T). Besides, Lugli et al., [54] found that loss of CDX2 expression is associated with a higher T stage in mismatch repair-proficient (MSS or MSIlow) CRCs. There was statistically significant inverse relation between CDX2 immunohistochemical staining and lymph node status $(\mathrm{N})$. Loss of CDX2 immunohistochemical staining increased with increased lymph nodes metastasis (N). Similarly, Choi et al., [51] and Bae et al., [24] reported that loss of CDX2 expression was significantly associated with lymph node status (N). Besides, Kim et al., [50] found that CDX2 loss was significantly associated with lymph node metastasis in MSI-H CRC tissues and Lugli et al., [54] found that the loss of CDX2 expression is associated with a higher $\mathrm{N}$ stage in mismatch repair-proficient (MSS or MSI-low) CRCs. There was statistically significant inverse relation between CDX2 immunohistochemical staining and distant metastasis (M). Loss of CDX2 immunohisto-chemical staining is more common in cases with distant metastasis than those with no distant metastasis. Similarly, Bae et al., [24] reported that loss of CDX2 expression was significantly associated with distant metastasis (M). There was statistically significant inverse relation between CDX2 immunohistochemical staining and the tumor stage. Loss of CDX2 immunohistochemical staining increased with increased stage of the tumor. Similarly, Oslen et al., [23] and Bae et al., [24] reported that loss of CDX2 expression was significantly associated with tumor stage. In contrast, Oslen et al., [53] reported that cancer stage was not significantly associated with CDX2 protein level. There was statistically significant inverse relation between CDX2 immunohistochemical staining and vascular invasion. Loss of CDX2 immunohistochemical staining is more common in cases with vascular invasion than those with no vascular invasion. Similarly, Knösel et al., [52] reported that loss of CDX2 was significantly correlated with vascular invasion. Besides, Lugli et al., [54] found that loss of CDX2 expression is associated with more frequent vascular invasion in mismatch repair-proficient (MSS or MSI-low) CRCs. 
The relation between Cox 2 immunohistochemical score and CDX2 immunohistochemical staining in the studied colorectal carcinoma cases was statistically significant.

Therefore, we conclude that combined expression of Cox 2 with loss of CDX2 suggests poor prognosis and high risk of metastasis in patients with colorectal cancer. Therefore, this combination could be used for evaluating the prognosis and screening for patients with high risk of metastasis.

\section{Conflict of interest:}

None declared.

\section{References}

1- HAN S., WANG J., WANG L., et al.: The role of RCAS 1 as a biomarker in diagnosing CRC and monitoring tumor recurrence and metastasis. Tumor. Biol., 35: 6149-57, 2014.

2- RASKOV H., POMMERGAARD H.C., BURCHARTH J., et al.: Colorectal carcinogenesis-update and perspectives. World J. Gastroenterol., 20: 18151-64, 2014.

3- SIEGEL R.L., MILLER K.D. and JEMAL A.: Cancer statistics, 2016. CA: A Cancer Journal for Clinicians, 66 (1): 7-30, 2016.

4- LÓPEZ P.J.T., ALBERO J.S. and RODRÍGUEZ-MONTES J.A.: Primary and secondary prevention of colorectal cancer. Clin. Med. Insights: Gastroenterol., 7: 33-46, 2014.

5- IBRAHIM A.S., KHALED H.M., MIKHAIL N.N., et al.: Cancer incidence in Egypt: Results of the national population-based cancer registry program. J. Cancer Epidemiol., 2014.

6- METWALLY I.H., SHETIWY M., ELALFY A.F., et al.: Epidemiology and survival of colon cancer among Egyptians: A retrospective study. J. Coloproctol., 2017.

7- MAHFOUZ EM., SADEK R.R., ABDEL-LATIEF W.M., et al.: The role of dietary and lifestyle factors in the development of colorectal cancer: Case control study in Minia, Egypt. Cent. Eur. J. Public Health, 22 (4): 21522, 2014.

8- KAZEM A., EL-SAYED K., EL-KERM Y., et al.: Prognostic significance of $\mathrm{COX} 2$ and $\mathrm{B}$-catenin in colorectal carcinoma. Alex. J. Med., 50: 211-20, 2014.

9- FODA A.A.M., EL-HAWARY A.K., AZIZ A.A., et al. Rare mucinous colorectal adenocarcinoma: Analysis of the epidemiological factors in relation to survival in Egyptian patients. Am. J. Cancer Epidemiol. Prevent., 2: 10-9, 2014

10-TEJPAR S.: The use of molecular markers in the diagnosis and treatment of colorectal cancer. Best. Pract. Res. Clin. Gastroenterol., 21: 1071-87, 2007.

11-FLOSSMANN E. and ROTHWELL P.M.: Effect of aspirin on long-term risk of colorectal cancer: Consistent evidence from randomised and observational studies. Lancet, 369 (9573): 1603-13, 2007.
12- COOPER K., SQUIRES H., CARROLL C., et al.: Chemoprevention of colorectal cancer: Systematic review and economic evaluation. Health Technol. Assess., 14 (32): 1-206, 2010.

13- MYUNG S.J. and KIM I.H.: Role of prostaglandins in colon cancer. Korean J. Gastroenterol., 51 (5): 274-9, 2008.

14- LIM S.C., CHO H. and LEE T.B.: Impacts of Cytosolic Phospholipase A2, 15-Prostaglandin Dehydrogenase, and Cyclooxygenase-2 Expressions on Tumor Progression in Colorectal Cancer. Yonsei Med. J., 51 (5): 692-9, 2010.

15- LIU B., QU L. and YAN S.: Cyclooxygenase-2 promotes tumor growth and suppresses tumor immunity. Cancer Cell Int., 15: 106, 2015.

16- PERISA M.M., SARCEVIC B., TROSELJ K.G., et al.: Expression of $n m 23-\mathrm{H} 1$ and $\mathrm{COX}-2$ in thyroid papillary carcinoma and microcarcinoma. Oncology Letters, 13 (5): 3547-55, 2017.

17- WANG D. and DUBOIS R.N.: Eicosanoids and cancer. Nat. Rev. Cancer, 10: 181-93, 2010.

18-WANG D., WANG H., SHI Q., et al.: Prostaglandin E (2) promotes colorectal adenoma growth via transactivation of the nuclear peroxisome proliferator-activated receptor delta. Cancer Cell, 6: 285-95, 2004.

19- VERZI M.P., SHIN H., HO L.L., et al.: Essential and redundant functions of caudal family proteins in activating adult intestinal genes. Mol. Cell Biol., 31: 2026-39, 2011.

20- SIMMINI S., BIALECKA M., HUCH M., et al.: Transformation of intestinal stem cells into gastric stem cells on loss of transcription factor CDX2. Nat. Commun., 5: $5728,2014$.

21- BAI Y.Q., MIYAKE S., IWAI T., et al.: CDX2, a homeobox transcription factor, upregulates transcription of the p21/WAF1/CIP1 gene. Oncogene, 22: 7942-9, 2003.

22- GAO N., WHITE P. and KAESTNER K.H.: Establishment of intestinal identity and epithelial-mesenchymal signaling by Cdx2. Developmental cell, 16 (4): 588-99, 2009.

23- OLSEN J., ESPERSEN M.L.M., JESS P., et al.: The clinical perspectives of CDX2 expression in colorectal cancer: A qualitative systematic review. Surg. Oncol., 23: 167-76, 2014

24- BAE J.M., LEE T.H., CHO N.Y., et al.: Loss of CDX2 expression is associated with poor prognosis in colorectal cancer patients. World J. Gastroenterol., 21: 1457-67, 2015.

25- BONHOMME C., DULUC I., MARTIN E., et al.: The $\mathrm{Cdx} 2$ homeobox gene has a tumour sup pressor function in the distal colon in addition to a homeotic role during gut development. Gut., 52 (10): 1465-71, 2003.

26- WERLING R.W., YAZIJI H., BACCHI C.E., et al.: CDX2, a highly sensitive and specific marker of adenocarcinomas of intestinal origin: An immunohistochemical survey of 476 primary and metastatic carcinomas. The American Journal of Surgical Pathology, 27 (3): 303-10, 2003.

27- SLATTERY M.L., HERRICK J., WOLFF R.K., et al.: CDX2 VDR polymorphism and colorectal cancer. Cancer Epidemiology and Prevention Biomarkers, 16 (12): 27525, 2007. 
28- SUBTIL C., GUÉRIN E., SCHNEIDER A., et al.: Frequent rearrangements and amplification of the CDX2 homeobox gene in human sporadic colorectal cancers with chromosomal instability. Cancer Lett., 247: 197-203, 2007.

29- SALARI K., SPULAK M.E., CUFF J., et al.: CDX2 is an amplified lineage-survival oncogene in colorectal cancer. Proc. Natl. Acad. Sci. U.S.A., 109: E3196-205, 2012.

30- FLEMING M., RAVULA S., TATISHCHEV S.F., et al.: Colorectal carcinoma: Pathologic aspects. J. Gastrointest. Oncol., 3 (3): 153-73, 2012.

31- KOURIE H.R., GHORRA C., RASSY M., et al.: Digestive neuroendocrine tumor distribution and characteristics according to the 2010 WHO classification: A single institution experience in Lebanon. Asian Pac. J. Cancer Prev., 17 (5): 2679-81, 2016.

32- BaRRESI V., REGGIANI L.B., IENI A., et al.: Histological grading in colorectal cancer: New insights and perspectives. Histol. Histopathol., 30 (9): 1059-67, 2015.

33- JESSUP J.M., GOLDBERG R.M., ASARE E.A., et al.: Colon and rectum. In: Amin MB., Edge SB., Greene FL., et al. (eds): American Joint Committee on cancer (AJCC) cancer staging manual (ed8). Springer, 20: 251-74, 2017.

34- ELZAGHEID A., EMAETIG F., ALKIKHIA L., et al.: High cyclooxygenase-2 expression is associated with advanced stages in colorectal cancer. Anticancer. Res., 33: 3137-43, 2013.

35- WU Q.B. and SUN G.P.: Expression of COX-2 and HER2 in colorectal cancer and their correlation. World $\mathrm{J}$. Gastroenterol., 21 (20): 6206-14, 2015.

36- BONETTI L.R., LIONTI S. and VITARELLI E.: Prognostic significance of CDX2 immunoexpression in poorly differentiated clusters of colorectal carcinoma. Virchows Arch., 471 (6): 731-41, 2017.

37- YAMAUCHI T., WATANABE M., KUBOTA T., et al.: Cyclooxygenase- 2 expression as a new marker for patients with colorectal cancer. Dis. Colon. Rectum., 45: 98-103, 2002.

38- SOUMAORO L.T., UETAKE H., HIGUCHI T., et al.: Cyclooxygenase-2 expression: A significant prognostic indicator for patients with colorectal cancer. Clin. Cancer Res., 10: 8465-71, 2004.

39- OKUDUR S.S., ÖZER M.T. and DEMIRBAŞ S.: Prognostic Importance of Increased Cyclooxygenase-2 Levels in Colorectal Carcinomas: A 5-Year Single-Institution Study. The Eurasian Journal of Medicine, 40 (1): 6, 2008.

40- AL-MAGHRABI J., BUHMEIDA A., EMAM E., et al.: Cyclooxygenase- 2 expression as a predictor of outcome in colorectal carcinoma. World J. Gastroenterol., 18: 17939, 2012.

41- FUX R., SCHWAB M., THON K.P., et al.: Cyclooxygenase-2 expression in human colorectal cancer is unrelated to overall patient survival. Clin. Cancer Res., 11: 4754$60,2005$.
42- LIM S.C., LEE T.B., CHOI C.H., et al.: Prognostic significance of cyclooxygenase-2 expression and nuclear p53 accumulation in patients with colorectal cancer. J. Surg. Oncol., 97: 51-6, 2008.

43- WU A.W., GU J., JI J.F., et al.: Role of COX2 in carcinogenesis of colorectal cancer and its relationship with tumor biological characteristics and patients' prognosis. World J. Gastroenterol., 9: 1990-4, 2003.

44- YAMAC D., CELENKOGLU G., COSKUN U., et al.: Prognostic importance of COX2 expression in patients with colorectal cancer. Pathol. Res. Pract., 201: 497-502, 2005.

45- XIONG B., SUN T.J. and HU W.D.: Expression of cyclooxygenase- 2 in colorectal cancer and its clinical significance. World J. Gastroenterol., 11 (8): 1105-8, 2005.

46- SHIN I.Y., SUNG N.Y. and LEE Y.S.: The Expression of Multiple Proteins as Prognostic Factors in Colorectal Cancer: Cathepsin D, p53, COX-2, Epidermal Growth Factor Receptor, C-erbB-2, and Ki-67. Gut and Liver, 8 (1): 13-23, 2014.

47- MAHMOUD A.S., UMAIR A. and AZZEGHAIBY S.N.: Expression of Cyclooxygenase-2 (COX-2) in Colorectal Adenocarcinoma: An Immunohistochemical and Histopathological Study. Asian Pac. J. Cancer Prev., 15 (16): 6787-90, 2014.

48- WAN X.B., PAN Z.Z., REN Y.K., et al.: Expression and clinical significance of metastasis-related tumor markers in colorectal cancer. Ai Zheng, 28: 950-4, 2009.

49- DALERBA P., SAHOO D. and PAIK S.: CDX2 as a Prognostic Biomarker in Stage II and Stage III Colon Cancer. N. Engl. J. Med., 374 (3): 211-22, 2016.

50- KIM J.H., RHEE Y.Y. and BAE J.M.: Loss of CDX2/CK20 expression is associated with poorly differentiated carcinoma, the $\mathrm{CpG}$ island methylator phenotype, and adverse prognosis in microsatellite-unstable colorectal cancer. Am. J. Surg. Pathol., 37 (10): 1532-41, 2013.

51- CHOI B.J., KIM C.J., CHO Y.G., et al.: Altered expression of CDX2 in colorectal cancers. Apmis., 114 (1): 50-4, 2006.

52- KNÖSEL T., CHEN Y. and HOTOVY S.: Loss of desmocollin 1-3 and homeobox genes PITX1 and CDX2 are associated with tumor progression and survival in colorectal carcinoma. Int. J. Colorectal. Dis., 27: 1391-9, 2012.

53- OLSEN J., EIHOLM S. and KIRKEBY L.T.: CDX2 downregulation is associated with poor differentiation and MMR deficiency in colon cancer. Experimental and molecular pathology, 100 (1): 59-66, 2016.

54- LUGLI A., TZANKOV A., ZLOBEC I., et al.: Differential diagnostic and functional role of the multi-marker phenotype CDX2/CK20/CK7 in colorectal cancer stratified by mismatch repair status. Mod. Pathol., 21: 1403-12, 2008. 


\section{التعبير الهيستوكيميائى المناعى لكوكس Y وسى دى اكس Y وعلاقته بتطور المرض فى سرطان القولون والمستقيم دئيم}

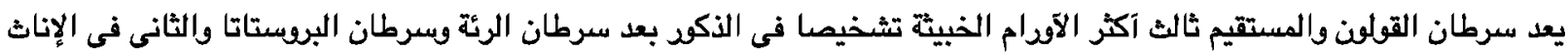

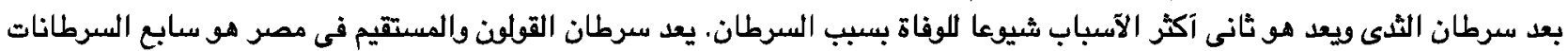

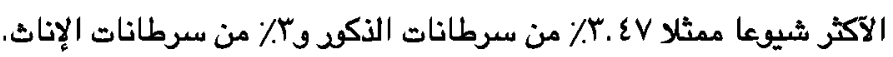

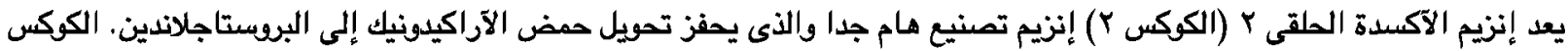

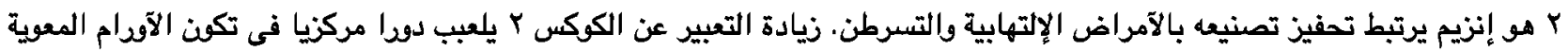

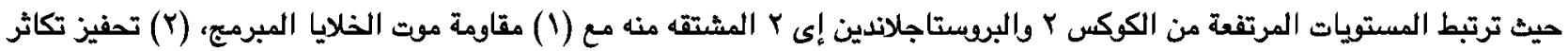
الخلايا، (r) تحفيز هجرة الخلايا و (ع) تولد الآوعية الدموية.

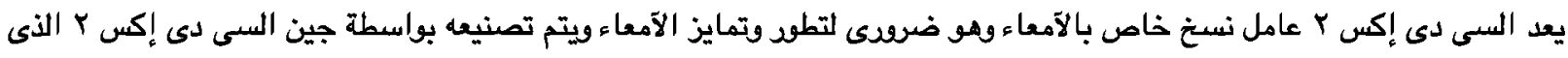

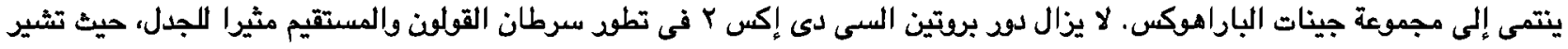

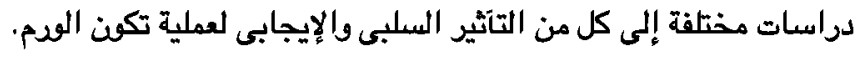

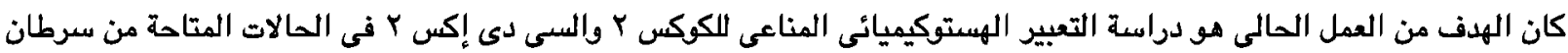

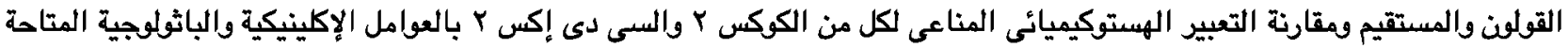

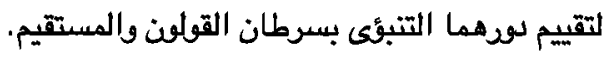

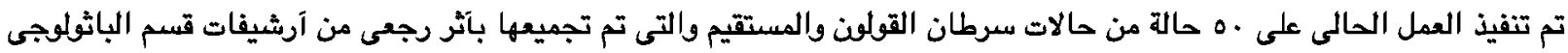

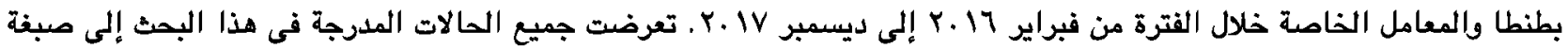

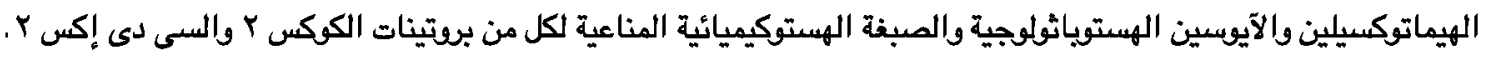

النتائج التى تم الحصول عليها:

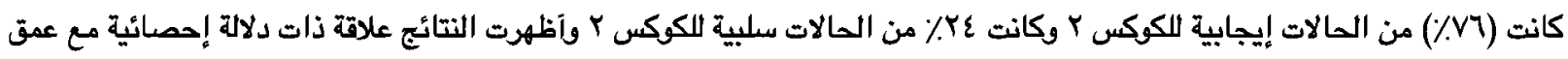

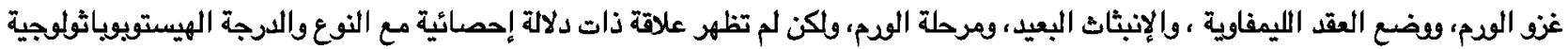
وغزو الآوعية الدموية والفزو العصبى.

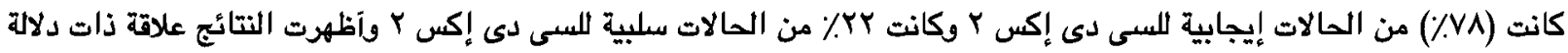

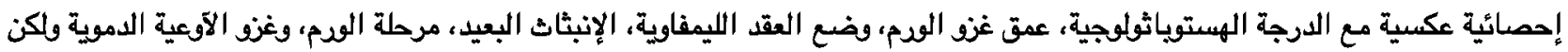

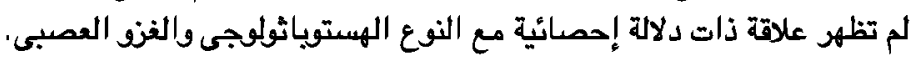
كانت العلاقة بين الناتج الهستوكيميائى المناعى اللكوكس ب والصبغة الهستوكيميائية للسى دى إكس ب فى الصالات المدرسية من سرطان القولون والمستقيم ذات دلالة إحصائية. من هذه الدراسة نستتّج آن: • يعد الكوكس r والسى دى إكس r دلالات ودمية هامة والتى تثارك فى عملية تكون سرطان القولمن والمستقيم وتشارك آيضا فى التنبئ بعرطان القولون والمستقيم.

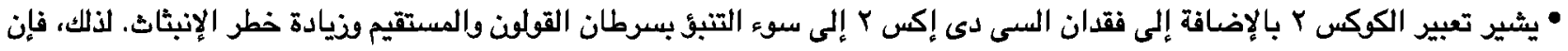

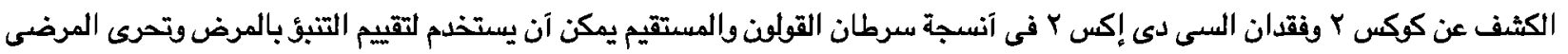
الذين يعانون من إرتفاع خطر الإنبثاث. 